\title{
Pengembangan Bahan Ajar Metode Numerik dengan PENDEKatan METAKognitif Berbantuan MATLAB
}

\author{
The DeVelopment of Numerical METhod Material Teaching Using \\ METACOGNITIVE ASSISTED MATLAB APPROACH
}

\author{
Mara Doli Nasution ${ }^{1}$, Elfrianto Nasution ${ }^{2}$ dan Feri Haryati ${ }^{3}$ \\ 1,2,3 Pendidikan Matematika, Universitas Muhammadiyah Sumatera Utara \\ 1 maradoli@yahoo.com
}

\begin{abstract}
Abstrak
Penelitian ini bertujuan untuk mengembangkan materi pembelajaran untuk metode numerik which dirancang dengan pendekatan metakognitif pemrograman dibantu matlab. Model pengembangan bahan pembelajaran menggunakan Penelitian dan Pengembangan (R \& D) WHO metode dikembangkan oleh Borg dan Gall dan dikombinasikan dengan model pengembangan pengajaran Dick dan Carey. Populasi untuk uji coba produk adalah mahasiswa UMSU jurusan pendidikan matematika. Instrumen which digunakan adalah kuesioner. Produk ini memiliki tiga langkah uji gruops Termasuk pribadi, gruops kecil dan lapangan. Sebelum uji coba produk, peneliti tidak ahli sidang validasi atas isi dan desain bahan pembelajaran untuk metode numerik dengan menggunakan kuesioner Menurut indikator yang telah ditentukan. Kemudian kuesioner dianalisis untuk melihat persentase dan kriteria validasi bahan Learning. Hasil dari penelitian ini adalah metode numerik yang dirancang diktat digunakan metakognitif pendekatan dibantu pemrograman Matlab.

Kata Kunci: Pendekatan metakognitif, pemrograman Matlab, metode numerik.
\end{abstract}

\begin{abstract}
This research aims to develop learning materials for numerical methods which be designed by Metacognitive approach assisted matlab programming. The development model of learning materials using Research and Development $(R \& D)$ methods who be developed by Borg and Gall and be combined with teaching development model Dick and Carey. The population for the product trials are UMSU students majoring in mathematics education. The instrument which be used is questionnaire. This products trials have three steps including personal gruops, small gruops and the field. Before products trials, the researcher does the expert validation trial for the content and design of learning materials for numerical methods using questionnaires according to the indicators that have been determined. Then the questionnaire be analysed to see the percentage and the validation criteria of Learning materials. The results of this research is a numerical method diktat be designed used metacognitive approach assisted matlab programming.

Keyword: metacognitive approach, matlab programming, numeric method.
\end{abstract}

\section{Pendahuluan}

Metode numerik merupakan salah satu mata kuliah yang dianggap sulit oleh mahasiswa pendidikan matematika.

Matakuliah tersebut digunakan untuk menyelesaikan persoalan matematis yang 
sulit dijawab

menggunakan metode

Berdasarkan hasil pra penelitian pada bulan mei 2013 terhadap mata kuliah metode numerik. menunjukkan kurangnya ketertarikan mahasiswa terhadap mata kuliah tersebut dan mahasiswa kurang aktif pada saat pembelajaran di kelas. Selain itu berdasarkan hasil observasi bahwa sulitnya ditemukan bahan ajar mata kuliah metode numerik yang berbantuan software di lingkungan pendidikan matematika Universitas Muhammadiyah Sumatera Utara.

Mahasiswa pendidikan matematika adalah calon pendidik atau guru matematika yang berperan aktif untuk meningkatkan kemampuan matematis siswa di masa akan datang. Oleh karena itu, peran dosen pendidikan matematika sangat diperlukan untuk meningkatkan kemampuan matematis mahasiswa calon guru. Committee on Undergraduate Program in Mathematics (CUPM) (dalam Novaliyoshi, 2011) merekomendasikan bahwa setiap matakuliah dalam matematika hendaknya dapat membantu mahasiswa dalam pengembangkan kemampuan analisis, penalaran kritis, pemecahan masalah dan keterampilan komunikasi.

Untuk memiliki kualifikasi akademik dan kompetensi serta meningkatkan kemampuan matematis mahasiswa sebagai calon pendidik atau guru maka dosen sebagai fisilitator perlu menciptakan proses pembelajaran yang menarik. Menurut Peraturan Pemerintah Nomor 32
Tahun 2013 tentang Standar Nasional Pendidikan menyatakan bahwa pendidik harus memiliki kualifikasi akademik dan kompetensi sebagai agen pembelajaran, sehat jasmani dan rohani, serta memiliki kemampuan untuk mewujudkan tujuan pendidikan nasional. Yang dimaksud pendidik sebagai agen pembelajaran (learning agent) adalah peran pendidik antara lain sebagai fasilitator, motivator, pemacu, dan pemberi inspirasi belajar bagi peserta didik. Menurut Peraturan Menteri tahun 2013 tentang standar nasional pendidikan tinggi menyatakan bahwa proses pembelajaran harus dilaksanakan secara interaktif, menyenangkan, menantang dan memotivasi mahasiswa untuk berpatisipasi aktif, serta memberikan kesempatan untuk berkreativitas dan mandiri.

Bahan ajar merupakan bagian yang perlu disediakan dalam proses pembelajaran. Daries (1981) menyatakan bahwa bahan ajar adalah sebuah sumber pembelajaran yang lebih spesifik yang mengandung tahapan dalam pengembangan, instruksional sehingga mahasiswa dapat belajar sesuai dengan langkah mereka sendiri berdasarkan kebutuhan individu dan kemampuannya. Menurut Yaumi (2013) bahwa fungsi bahan ajar dalam proses pembelajaran adalah sebagai representasi sajian dosen, sarana pencapaian standar kompetensi dan tujuan pembelajaran serta dapat mengoptimalisasikan pelayanan terhadap peserta didik. 
Untuk mewujudkan fungsi bahan ajar tersebut maka perlu diperhatikan segala sesuatu yang mendukung keberhasilan proses pembelajaran. Yaumi (2013) menyatakan bahwa perlunya mempertimbangkan konsep, jenis dan langkah-langkah dalam pengembangan bahan ajar. Sutikno (2013) menyatakan bahwa kehadiran media dalam proses pembelajaran mempunyai pengaruh yang besar terhadap tujuan pembelajaran, menghilangkan kebosanan mahasiswa dan meningkatkan motivasi mahasiswa dalam belajar. Selain itu, Novitasari (2011) menyatakan bahwa pembelajaran matematika dengan menggunakan media berupa software dapat menjadikan proses pembelajaran menjadi lebih effisien.

Noornia (2011) menyatakan bahwa pendekatan metakognitif dalam proses pembelajaran dapat meningkatkan kemampuan berpikir matematis dan kemandirian belajar. Selain itu, menurut Haryati (2012) menyatakan bahwa pendekatan metakognitif merupakan suatu pendekatan yang berpusat pada mahasiswa, sehingga mahasiswa menjadi termotivasi dan mandiri dalam proses pembelajaran.

Dari uraian masalah dan pendapatpendapat yang telah diungkapkan di atas, maka perlunya pembuatan bahan ajar mata kuliah metode numerik dengan pendekatan metakognitif berbantuan matlab, yang merupakan bahan ajar yang mengikuti perkembangan ilmu pengetahuan dan teknologi. Melalui bahan ajar tersebut diharapkan mahasiswa tertarik terhadap mata kuliah metode numerik dan proses pembelajaran menjadi interaktif, menyenangkan, menantang dan memotivasi mahasiswa untuk berpatisipasi aktif, serta memberikan kesempatan untuk berkreativitas dan mandiri. Oleh karena itu penulis mengajukan suatu penelitian yang berjudul "Pengembangan Bahan Ajar Mata Kuliah Metode Numerik dengan Pendekatan Metakognitif Berbantuan Matlab" dengan harapan dapat berguna sebagai bahan ajar untuk perbaikan pembelajaran berikutnya.

Bertolak dari masalah di atas, permasalahan dalam penelitian ini dirumuskan sebagai berikut: Bagaimana mengembangkan bahan ajar mata kuliah metode numerik dengan pendekatan metakognitif berbantuan matlab?

Metode Numerik adalah teknik-teknik yang digunakan untuk merumuskan masalah-masalah matematika agar dapat diselesaikan. Perhitungan dalam metode numerik melibatkan sejumlah besar operasi hitungan yang berulang. Banyak masalah matematika yang tidak dapat diselesaikan secara analitis tetapi dapat diselesaikan menggunakan metode numerik.

Mahasiswa pendidikan matematika mempelajari mata kuliah metode numerik pada semester enam. Adapun materi yang dipelajari pada mata kuliah metode numerik adalah persamaan tak linier, Persamaan linier, Interpolasi, Integrasi numerik, Penurunan fungsi secara numerik, dan penyelesaian persamaan difrensial secara numerik. 
Metakognisi memiliki dua kata dasar yaitu meta dan kognisi. Meta berarti setelah atau melebihi dan kognisi berarti keterampilan yang berhubungan dengan proses berpikir.

Pendekatan metakognitif mengarahkan perhatian mahasiswa terhadap materi yang relevan dan membimbing mereka untuk memilih strategi yang tepat untuk menyelesaikan soal-soal melalui pertanyaan metakognitif seperti apa yang kamu pahami terhadap masalah tersebut ? strategi apa yang kamu butuh untuk menyelesaikan masalah tersebut? apa yang salah dari yang telah kamu lakukan, atau jika ini benar, maka apa yang akan terjadi ? mengapa kamu lakukan begitu ? jika begini .? apa ada cara lain?. Menurut Fauzi (2011) metakognisi memiliki peranan penting dalam merancang (planning), memonitor (monitoring) serta mengevaluasi (evaluation) pengetahuan yang dimiliki untuk kemudian dikembangkan menjadi tindakan (action).

Kebiasaan berpikir matematis yang dibangun melalui pendekatan metakognitif adalah bertanya pada diri sendiri tentang apakah yang dibutuhkan untuk menyelesaikan suatu masalah dan bagaimana proses menyelesaikannya. Menurut Jendriadi (2009) menyatakan bahwa bertanya adalah salah satu teknik yang paling baik dalam proses pembelajaran. Selain itu menurut Fauzi (2011) bahwa pertanyaan yang diberikan hendaknya mengandung pertanyaan untuk menggiring (promting questions), menggali (probing questions) dan menggeneralisasi (generalisation questions). Oleh karena itu, perlunya memunculkan pertanyaan metakognitif kepada mahasiswa melalui bahan ajar untuk mengungkapkan keingintahuan mereka.

Kebiasaan bertanya pada diri sendiri dapat mengarahkan mahasiswa untuk membangun pengetahuan dan strategi mereka dalam menyelesaikan masalah sehingga mahasiswa menyadari akan kemampuan kognitif yang dimilikinya dan mengaitkan pengetahuan baru yang sedang dipelajari. Menurut Scheinde dan Artelt (2010) menyatakan bahwa metakognitif memiliki pengaruh terhadap kualitas pembelajaran. Selain itu, Fauzi (2011) menyatakan pembelajaran dengan pendekatan metakognitif dapat meningkatkan kemampuan komunikasi dan kemandirian belajar seseorang.

Setelah memberikan pertanyaan tersebut diharapkan adanya proses metakognitif dalam diri mahasiswa sehingga dapat berpengaruh berpengaruh terhadap perilaku matematisnya. Menurut Goos (1995) bahwa proses metakognitif mempengaruhi perilaku matematis seseorang. Oleh karena itu, pertanyaanpertanyaan metakognitif perlu dimunculkan pada saat interaksi dikelas maupun pada bahan ajar untuk mendorong mahasiswa menemukan dan menggunakan strategi dalam memecahkan masalah matematika.

Matlab adalah sebuah program yang digunakan untuk menganalisis dan menghitung secara numerik dengan 
menggunakan bahasa pemograman matematika lanjutan. Menurut Sianifar (2013) menyatakan bahwa matlab dapat digunakan untuk menyelesaikan permasalahan matematis dan alat bantu dalam proses pembelajaran. Beberapa konsep matematika yang dapat diuraikan dengan menggunakan matlab diantaranya adalah matriks, vektor, aljabar linier, interpolasi, integral dan difrensial biasa.

Sebagai sebuah system, matlab terdiri dari 5 bagian yaitu:

1. Development Environment.

Development Environment adalah kumpulan perangkat yang dapat membantu untuk menggunakan fungsifungsi pada matlab. Perangkat ini merupakan sebuah graphical user interfaces (GUI) yang terdiri dari desktop, command window, command history, sebuah editor dan debugger, dan browsers untuk melihat help, workspace, files, dan search path.

2. Mathematical Function Library

Mathematical function library terdiri dari algoritma komputasi mulai dari fungsifungsi dasar sepetri: sum, sin, cos, complex arithmetic, matrix inverse, matrix eigenvalues, Bessel functions, dan fast Fourier transforms.

\section{MATLAB Language}

Matlab language terdiri dari high-level language dengan control flow statements, functions, data structures, input/output, dan fitur-fitur object-oriented programming.

4. Graphics
Matlab memiliki fasilitas untuk menampilkan vektor dan matriks sebagai suatu grafik. Terdapat high-level functions (fungsi-fungsi level tinggi) yang dapat menvisualisasi dalam bentuk dua dimensi, tiga dimensi, proses pembuatan latar suatu gambar, animasi, selain itu terdapat juga fungsi level rendah.

\section{Metode}

\section{A. Model Pengembangan Bahan Ajar}

Metode penelitian yang digunakan adalah penelitian pengembangan (developmental research). Menurut Borg dan Gall (1983), pendekatan Research and Development (R \& D) dalam pendidikan meliputi beberapa langkah- langkah, yaitu:

1. Melakukan analisis masalah dan kebutuhan untuk mengumpulkan informasi berupa kajian pustaka metode numerik, menentukan SAP dan menentukan tujuan pembelajaran tersebut.

2. Melakukan perencanaan produk/bahan ajar metode numerik dan pembuatan instrumen berupa angket tentang kualitas bahan ajar dilihat dari komponen materi, penyajian dan bahasa.

3. Penyusunan bahan ajar metode numerik dengan pendekatan metakognitif berbantuan matlab

4. Melakukan validasi ahli dengan menggunakan angket validasi. Melakukan revisi terhadap produk utama, berdasarkan masukan dan saran-saran-saran dari hasil validasi ahli. 
5. Melakukan revisi terhadap produk dari hasil penilaian validasi ahli

6. Uji coba bahan ajar (produk) terhadap kelompok perorangan, kecil dan lapangan mahasiswa universitas Muhammadiyah Sumatera Utara yang memiliki karakteristik siswa kemampuan rendah, sedang melalui angket (kuesioner) yang diberikan.

7. Hasil akhir, merupakan produk bahan ajar metode numerik yang sudah selesai direvisi dan siap diterapkan pada pembelajaran.

\section{B. Tahap Uji Coba Bahan Ajar (Produk)}

Tahap uji coba ini terdiri dari tiga tahapan, sebagai berikut: 1) Desain uji coba; 2) Subjek uji coba; dan Pelaksanaan uji coba.

Desain uji coba terdiri dari beberapa tahapan yaitu: a) Validasi ahli; b) validasi design pembelajaran; c) revisi pengembangan berdasarkan penilaian dari 2 ahli isi dan 2 ahli desain pembelajaran dengan pendekatan metakognitif berbantuan matlab (uji tahap I); d) uji coba bahan ajar oleh 5 mahasiswa (uji coba perorangan) dan 10 mahasiswa (uji coba kelompok kecil; e) revisi produk (uji tahap II); f) uji coba lapangan terhadap mahasiswa; g) revisi produk ( uji tahap III).

Subjek uji coba adalah pemakai produk yaitu mahasiswa semester delapan Pendidikan Matematika Universitas Muhammadiyah Sumatera Utara.

Pelaksanaan uji coba melalui tiga tahapan yaitu:

1. Uji coba perorangan. Pada langkah ini bahan ajar telah direvisi berdasarkan saran dari beberapa ahli. Angket penilaian diberikan pada pemakai secara perorangan dengan tujuan untuk mengetahui kesahihan produk setelah diperbaiki dari tim ahli isi dan desain. Masukan -masukan dari uji coba perorangan selanjutnya dipakai sebagai dasar dalam melakukan perbaikan terhadap produk.

2. Uji coba kelompok kecil. Uji coba ini untuk mengetahui apakah terdapat kekurangan yang perlu diperbaiki dari produk setelah revisi dari ahli dan uji coba perorangan. Jika terdapat kekurangan maka akan dilakukan revisi.

3. Uji coba lapangan. Uji coba ini dilakukan untuk mengetahui apakah masih terdapat kekurangankekurangan yang perlu diperbaiki dari bahan ajar yang dikembangkan setelah diskusi dengan tim ahli dan hasil uji coba kelompok perorangan dan kelompok kecil.

\section{Teknik Pengumpulan Data}

Teknik pengumpulan data pada penelitian ini diperoleh dari data kuesioner berupa angket.

\section{Teknik Analisis Data}

Data dalam penelitian ini merupakan data deskriptif persentase. Dalam analisis deskriftif persentase, perhitungan yang digunakan untuk mengetahui kriteria validasi bahan ajar berdasarkan persentase skor dari angket. Kriteria skor penilaian validasi analisis nilai rata-rata yang digunakan seperti tercantum pada tabel 1 berikut: 
Tabel 1.

Kriteria Validasi Bahan Ajar

\begin{tabular}{|cc|}
\hline Persentase (\%) & Kriteria Validasi \\
\hline $80 \% \leq x<100 \%$ & Sangat baik \\
\hline $60 \% \leq x<80 \%$ & Baik \\
\hline $40 \% \leq x<60 \%$ & Sedang \\
\hline $20 \% \leq x<40 \%$ & Kurang Baik \\
\hline $0 \% \leq x<20 \%$ & Sangat kurang baik \\
\hline
\end{tabular}

\section{Hasil dan Pembahasan}

Hasil Penelitian pada penelitian ini berupa diktat metode numerik dengan pendekatan metakognitif berbantuan matlab, adapun hasil yang diperoleh dalam penelitian ini dan diktat yang dirancang adalah:

\section{A. Kompetensi Mata Kuliah}

Setelah menyelesaikan matakuliah Metode Numerik mahasiswa akan memiliki kemampuan-kemampuan:

1. Menentukan galat suatu hampiran numerik.

2. Menggunakan metode numerik yang sesuai untuk menentukan hampiran penyelesaian suatu SPL
3. Menggunakan metode numerik yang sesuai untuk menghitung hampiran penyelesaian suatu persamaan tak linier

4. Menggunakan metode numerik (interpolasi) yang sesuai untuk menghitung hampiran nilai suatu fungsi

5. Menggunakan metode numerik yang sesuai untuk menghitung hampiran nilai turunan suatu fungsi

6. Menggunakan metode numerik yang sesuai untuk menghitung hampiran nilai integral suatu fungsi.

7. Menggunakan metode numerik yang sesuai untuk menghitung hampiran penyelesaian persamaan diferensial biasa (masalah nilai awal).

Kompentensi-kompetensi tersebut saling terkait dan mendukung pencapaian tujuan umum perkuliahan Metode Numerik, sebagaimana digambarkan dalam diagram berikut ini.

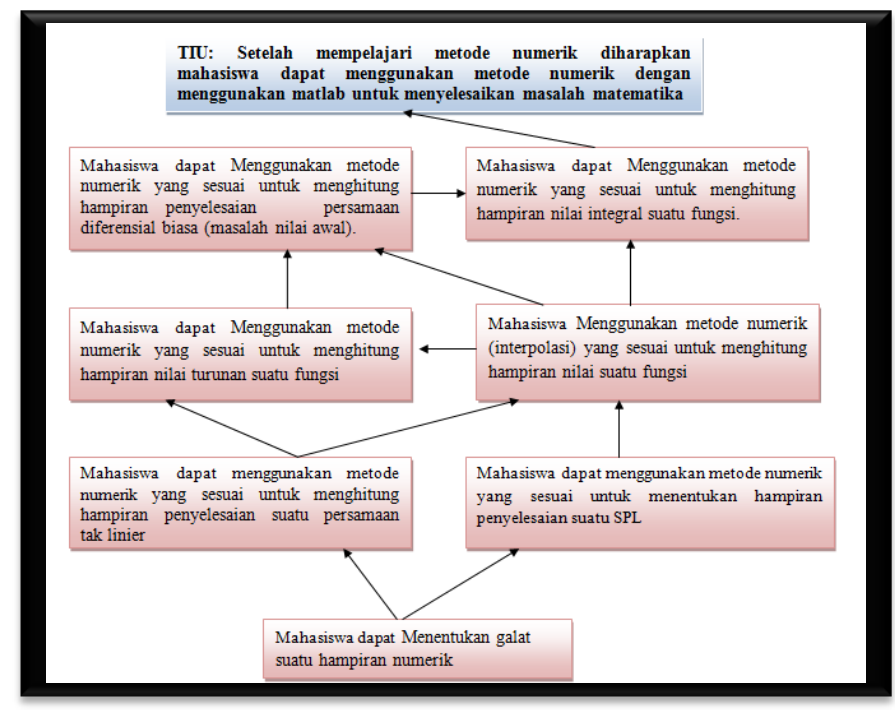

Gambar 1. Kompetensi Perkuliahan Metode Numerik.

Berdasarkan silabus dan SAP yang numerik. Berikut ini ada produk dari diktat dibuat maka diperoleh diktat metode yang dirancang. 


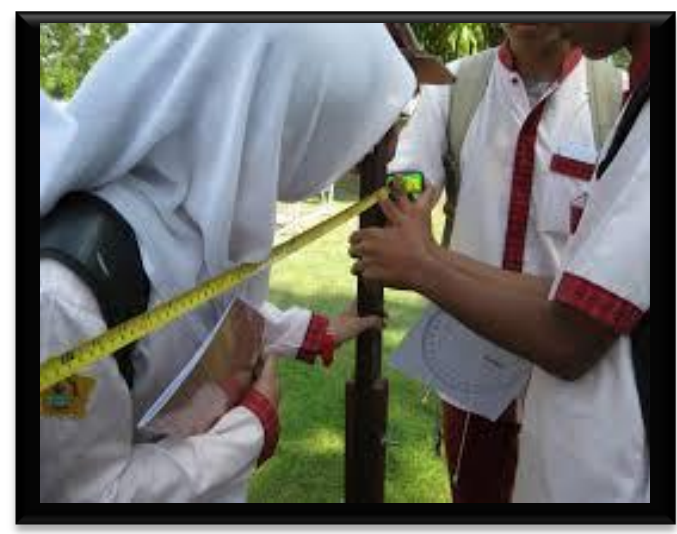

Gambar 2. Produk 1.

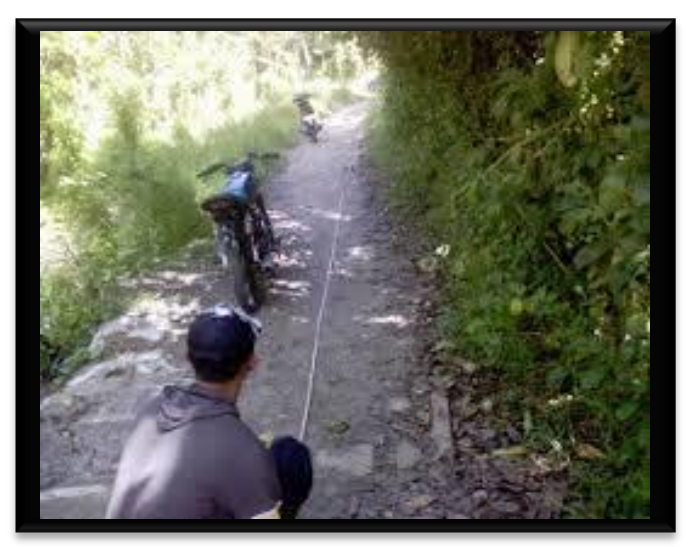

Gambar 3. Produk 2.

Perhatikan gambar (2) dan (3).

Gambar (2): Beberapa siswa mengukur panjang halaman sekolah. Hasil dari pengukuran menunjukkan panjang halaman sekolah 999 cm, sedangkan panjang halaman sebenarnya $1000 \mathrm{~cm}$. Hitunglah galat (kesalahan) absolut? Mohon diskusikan dengan temanmu.

Untuk menjawab soal di atas. Apa yang harus kamu lakukan? Pemahaman apa yang harus kamu ketahui sebelum menyelesaikan soal tersebut? Bagaimana kamu menyelesaikan soal tersebut? Periksa kembali jawabanmu, kemudian persentasikan di depan kelas.
Gambar (3): Pak Joko mengukur panjang jalan. Hasil dari pengukuran menunjukkan panjang tersebut $99999 \mathrm{~cm}$ (panjang jalan sebenarnya $100.000 \mathrm{~cm}$ ). Hitunglah galat (kesalahan) absolut? Mohon diskusikan dengan temanmu.

Untuk menjawab soal di atas. Apa yang harus kamu lakukan? Pemahaman apa yang harus kamu ketahui sebelum menyelesaikan soal tersebut? Bagaimana kamu menyelesaikan soal tersebut? Periksa kembali jawabanmu, kemudian persentasikan di depan kelas.

\section{B. Tahap Kemandirian}

Kerjakan soal dibawah ini dengan sendiri tanpa bertanya kepada temanmu. Kalau mengalami kesulitan silakan ditanyakan langsung kepada dosen.

Hitunglah galat, galat mulak dan galat relatif

1. Nilai $x=2,71828182$ dan $\bar{x}=2,7182$

2. Nilai $x=98750$ dan $\bar{x}=99000$

3. Nilai $x=\sqrt{2}$ dan $\bar{x}=1,414$

Untuk menjawab soal di atas. Apa yang harus kamu lakukan? Pemahaman apa yang harus kamu ketahui sebelum menyelesaikan soal tersebut? Bagaimana kamu menyelesaikan soal tersebut? Periksa kembali jawabanmu, kemudian persentasikan di depan kelas.

Sebelum menjawab pertanyaan diatas mohon dipelajari materi yang diberikan dibawah ini. Jika ada yang kurang paham mohon ditanyakan langsung kepada dosen.

1) Pengertian Metode Numerik

Metode numerik adalah suatu teknik penyelesaian yang diformulasikan dengan 
menggunakan operasi hitungan atau aritmatika yaitu hitungan biasa seperti tambah, kurang, kali, dan bagi yang dapat dilakukan secara berulang-ulang baik dengan bantuan komputer atau secara manual. Perhitungan tersebut melibatkan angka -angka sejumlah besar dengan operasi-operasi hitungan yang berulangulang, melelahkan, dan menjemukan.

Dalam menganalisis suatu permasalahan yang didekati dengan menggunakan metode numerik selalu melibatkan angka dan melewati proses perhitungan matematika yang cukup rumit. Perhitungan secara manual membutuhkan waktu lama. Namun dengan adanya software matematika saat ini dapat membantu permasalahan penyelesaian dengan mudahdan cepat. Salah satu contoh software yang dapat membantu permasalahan numerik adalah MATLAB.

Metode numerik sudah baku dan telah luas pemakaiannya. Metode numerik yang baru pada hakekatnya bertujuan menemukan cara perhitungan yang dapat membuat galat (error) sekecil mungkin dan memberikan metode-metode yang efisien untuk memperoleh jawaban numerik dari bermacam-macam permasalahan.

2) Penyelesaian Masalah Matematika

Heading level 2 ditulis dengan format; title case, rata kiri, bold, Calibri 12 , spasi 1.15, dengan penomoran huruf besar diikuti titik.

Terdapat dua cara dalam menyelesaikan permasalahan, yaitu: a. Secara analisis, yaitu suatu cara penyelesaian permasalahan matematika dengan menggunakanoperasi matematika dan menggunakan rumusrumus yang sudah tersedia sehingga diperoleh solusi eksak yang memiliki galat sama dengan nol.

b. Secara numeris, yaitu suatu cara penyelesaian permasalahan matematika dengan menggunakan metode numerik untuk memperoleh nilai solusi hampiran dari solusi eksak. Cara ini biasanya dilakukan jika nilai eksak sukar dicari dengan cara analisis.

Tahapan yang perlu dipersiapkan dalam menyelesaikan masalah matematika secara numerik dengan memakai software secara umum yaitu:

a. Pemodelan yaitu merumuskan permasalahan secara matematis dengan cara mendefinisikan variabel bebas dan tak bebas, dan persamaan baik persamaan linear atau tak linear, integral, sistem persamaan dan menyesuaikan jenis software matematika yang digunakan.

b. Pemrograman yaitu pembuatan diagram alir yang memperlihatkan prosedur yang harus dilaksanakan oleh komputer dan kemudian penulisan program dalam bahasa komputer, pencarian dan perbaikan kesalahan dan pengujian. 
c. Penafsiran hasil yaitu pemberian keterangan (penjelasan) dari hasil yang diperoleh.

3) Galat, Kesalahan Absolut dan Kesalahan Relatif

Galat numerik adalah besaran yang merupakan selisih antara nilai hampiran dengan nilai eksak. Hubungan ini dirumuskan menjadi:

$$
\mathrm{Ea}=x-\bar{x} \text { atau } x=\bar{x}+\mathrm{Ea}
$$

dimana Ea adalah galat absolut (galat mutlakL, $x$ nilai eksak, dan $\bar{x}$ nilai hampiran. Jika tanda galat (positif atau negatif) tidak dipertimbangkan, maka galat mutlak dapat didefinisikan sebagai:

$$
\left|\mathrm{E}_{\mathrm{a}}\right|=|x-\bar{x}|
$$

Galat relatif adalah galat absolut dibagi oleh nilai eksak, dinyatakan sebagai berikut:

$$
\mathrm{e}_{\mathrm{r}}=\frac{\text { galat absolut }}{\text { nilai } \text { eksak }}=\frac{E a}{x}
$$

untuk galat absolut dinyatakan dengan $E_{a}$ dan galat relatif dinyatakan dengan $\mathrm{e}_{\mathrm{r}}$.

Contoh Soal: Misalkan nilai eksak $=10 / 3$ dan nilai hampiran $=3.333$. Hitunglah galat, galat mutlak, dan galat relatif?

Penyelesaian:

galat $=10 / 3-3.333=10 / 3-$

$3333 / 1000=1 / 3000=0.000333 \ldots$

galatmutlak $=|0.000333 \ldots|=0.000333 \ldots$

galat relatif $=(1 / 3000) /(10 / 3)=1 / 1000=$ 0.0001

\section{4) Angka Signifikan}

Dalam matematika kita kenal dua klasifikasi bilangan real yaitu bilangan eksak dan non eksak. Bilangan eksak terdiri dari bilangan asli, bulat, rasional dan irasional (yang ditulis dalam bentuk 2, $\pi$, dan e, misalnya), sedangkan bilangan non eksak yang dikenal dengan sebutan bilangan aproksimasi yang merupakan bilangan hasil pembulatan (pendekatan atau hampiran) dari suatu bilangan eksak.

Bilangan-bilangan aproksimasi dinyatakan dengan bilangan yang mempunyai derajat ketelitian. Misalnya hasil aproksimasi $\pi$ adalah 3,1416 (teliti hingga empat tempat desimal) atau 3,14159265 (teliti hingga delapan tempat desimal), sedangkan nilai eksak dari $\pi$ adalah bilangan desimal tak terbatas sehingga tidak mungkin dapat ditulis. Jadi angka-angka yang menyatakan suatu bilangan disebut angka-angka signifikan. Jadi bilangan-bilangan 3,1416; 0,66667 dan 4,0687 masing-masing memuat lima angka signifikan. Bilangan 0,0023 hanya mempunyai dua angka signifikan yaitu 2 dun 3, karena nol hanya menentukan tempat dari titik desimal.

5) Pembulatan

Penulisan bilangan-bilangan yang tersusun panjang yang terdapat dibelakang tanda koma "," (versi indonesia) atau tanda titik "." (versi western) misalnya 12,345678912344 (versi indonesia) atau 12.345678912344 (versi western) yang memiliki 12 angka dibelakang tanda koma versi indonesia. Proses pemotongan bilangan seperti itu disebut Pembulatan.

Aturan pembulatan sampai $\mathrm{k}$ angka desimal adalah sebagai berikut:

a. Jika bilangan yang dibuang lebih kecil dari setengah satuan dalam posisi ke-k, biarkan angka desimal ke-k tetap. Cara ini disebut " pembulatan ke bawah". 
Contoh : 0,6234567 dibulatkan hingga 3 angka desimal menjadi 0,623.

b. Jika bilangan yang dibuang lebih besar dari setengah satuan dalam posisi ke-k, tambahkan satu pada angka desimal kek. Cara ini disebut "pembulatan ke atas".

Contoh: 0,6234567 dibulatkan hingga 4 angka desimal menjadi 0,6235.

c. Jika bilangan tersebut tepat setengah satuan, bulatkan ke angka desimal genap yang terdekat.

Contoh: 3,45 dan 3,55 dibulatkan ke 1 angka desimal menjadi 3,4 dan 3,6.

\section{Tahap Penyimpulan}

Kembali diskusikan dengan teman kelompokmu dan kemudian buatlah kesimpulan dari materi yang sudah kamu pelajari pada sebuah kertas dan kemudian persentasikan di depan kelas.

Jadi, hampiran penyelesaiannya adalah $\{(x, y, z)=(1,95 ; 3,96875 ; 2,98625)\}$.

Contoh: Tentukan nilai a, b, c, d ,e dari sistem persamaan berikut

1. $a+2 b+3 c+5 d+2 e=25$

2. $3 a+2 b+3 c+3 d-5 e=2$
3. $6 a+2 b+3 c-2 d-7 e=-11$

4. $11 a+9 b-2 c-2 d-4 e=0$

5. $33 a-3 b-3 c-4 d-6 e=2$

Lima persamaan di atas sudah dibuat sedemikian formatnya, yaitu dari kiri ke kanan urut variabel a, b, c, d, e, agar dalam pengerjaan di program matlab menjadi lebih mudah dan demi mengurangi kesalahan user dalam memasukkan angkaangka pada saat pengerjaan tersebut.

Maka, langsung saja masuk ke program matlab dan tuliskan seperti berikut dibawah, pada command window:

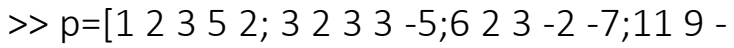

$2-2-4 ; 33-3-3-4-6]$;

$>\mathrm{q}=[25 ; 2 ;-11 ; 0 ;-2]$;

$>>$ p $\backslash \mathrm{q}\{$ tekan enter

ans $=$

1.0000

1.0000

2.0000

2.0000

$3.0000 \quad\{$ HASIL $\}$

Tampilan yang muncul pada matlab sebagai berikut:

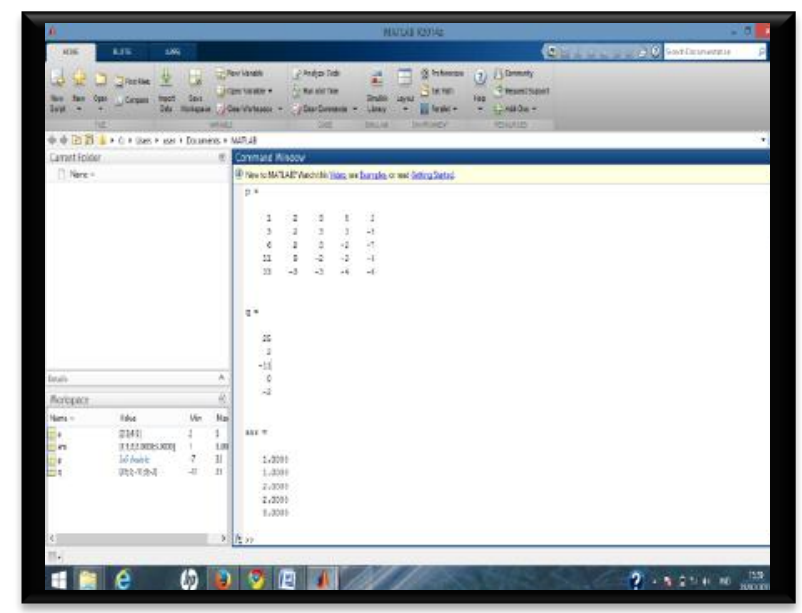

Gambar 4. Tampilan pada MATLAB. 


\section{Penutup}

Penelitian ini menghasilkan berupa silabus dan SAP, buku serta diktat metode numerik yang dirancang dengan pendekatan metakognitif berbantuan matlab. Besar harapan peneliti agar diktat ini bisa digunakan dalam pembelajaran khususnya mata kuliah metode numerik.

\section{Daftar Pustaka}

Borg. W.R. and Gall, M.D. (1987). Educational Reaserch: An Introduction. London: Longman, Inc.

Daries, I. (1981), Instructional Tenchnology and Media, MC Graw Hill Company, Newyork

Fauzi. A. (2011). Peningkatan Kemampuan Koneksi Matematis dan Kemandirian Belajar Siswa dengan Pendekatan Pembelajaran Metakognitif di Sekolah Menengah Pertama. Disertasi pada PPS UPI: Tidak diterbitkan.

Goos, M. (1995).Metacognitive Knowledge, Belief, and Classroom Mathematics. Eighteen Annual Conference of The Mathematics Education Research Group of Australasia, Darwin, July 7-10 1995.

Haryati, Feri. (2012). Peningkatan Kemampuan Pemecahan Masalah Dan Kemandirian Belajar Melalui Pembelajaran Dengan Pendekatan Metakognitif Berbasis Soft Skill. Tesis pada PPs UPI: Tidak diterbitkan

Munir, Renaldi. (2013). Metode Numerik. Bandung: Informatika Bandung.

Noornia, Anton. (2011). Cooperative Learning with Metacognitive
Approach Ton Enhance Mathematical Critical Thinking And Probelem Solving Ability And the Relation To Self Regulated Learning. Jurnal International Seminar and the 4th National Conference on Mathematics Education. Juni 2011

Novaliyosi. (2011). Meningkatkan Kemampuan Berpikir Kritis Matematis Dan Kemandirian Belajar Mahasiswa Melalui Pembelajaran Dengan Pendekatan Investigasi. Tesis pada SPs UPI: Tidak diterbitkan.

Presiden RI .(2013). Peraturan Pemerintah Republik Indonesia Nomor 32 Tahun 2013 Tentang Standar Nasional Pendidikan.

Schneider, W. \& Artelt, C. (2010). Metacognition and mathematics education. ZDM -The International Journal on Mathematics Education 42(2): 149-161.

Sianifar, R.H. (2013). Pemrograman Matlab. Bandung: Informatika Bandung

Sutikno, Sobry. (2013). Belajar dan Pembelajaran. Lombok: Holistica Yaumi, Muhammad. (2013). Prinsip-Prinsip Desain Pembelajaran. Jakarta: Kencana. 